\title{
A arte de Elifas Andreato
}

Cores, cores, muitas cores. Expressões delineadas e fortes. Músculos vibrantes, mesmo quando presos e cansados de tortura, lembram Vlado, Tiradentes, Guernica. Olhos e lábios feitos de riso e lágrima. Adoniran, Elis, Paulinho da Viola, Chico, Clara Nunes, Toquinho e tantos outros puderam ver-se pelos olhos do menino, ex-operário, cidadão Elifas. A dor é expressa com paixão. As formas ganham emoção, mostram-se vivas, quase falam, enunciam um discurso que transcende o político e realça a existência. As formas vivas que pulam do pincel têm cheiro, voz, personalidade. Muitos não conhecem o artista que optou pelas artes gráficas para não deleitar apenas as paredes das belas casas e dos museus. Começou com as pinturas do salão de festas na fábrica, migrou e expandiu-se para as capas de revistas, para as charges nos jornais alternativos, para os cartazes das peças de teatro, para as capas de discos e depois CDs da MPB, para os cenários no teatro, na televisão, para as ilustrações em livros, para as músicas e os livros infantis, tudo feito com opinião. Faz arte com respeito à vida, à liberdade e com compromisso coletivo. A camaradagem está estampada nas figuras que contam histórias: era uma vez, havia pessoas que sonhavam com um mundo melhor... São mais de quarenta anos pintados em cores firmes, traços marcantes e uma renovada alegria.

Por Roseli Fígaro

C \& E: Elifas, todos sabemos que você é autodidata. Você vem de uma trajetória de jovem operário, depois estagiário na Editora Abril. Como você se tornou um artista gráfico?

Elifas Andreato: Essa habilidade foi sendo moldada. Fui moldando-a à força. Como disse muitas vezes, sou filho de lavradores. Desde os oito anos trabalhei fazendo, na roça, serviço de criança: colher algodão, limpar cova de café, torrar amendoim para paçoca... Depois, já na cidade de São Paulo, trabalhei carregando cesta de feira e em outras atividades que toda criança brasileira pobre ainda faz. Desgraçadamente esse número aumentou muito. Por isso, sou um pouco avesso a me colocar como modelo, porque é uma grande tragédia. Sou um sobrevivente, mas milhares e milhares de crianças não conseguem. E também não sei, não tenho uma explicação de como consegui... Talvez minha mãe seja a razão da minha sobrevivência, porque é uma mulher muito forte, criou seis filhos, praticamente sozinha; meu pai era alcoólatra.

Na fábrica, aqui em São Paulo, estava aprendendo a ser torneiro mecânico. Trabalhava na oficina da fábrica de fósforos Fiat Lux, na Vila Anastácio. Era uma empresa que tinha oitocentas operárias, explorava a mão-de-obra feminina, isso em torno de 1964/1965. No ano do golpe militar, eu era um perfeito ignorante, estava me alfabetizando em um curso de alfabetização para adultos. Na fábrica, fiz um trabalho, ilustrando os jornais operários: desenhava charges 


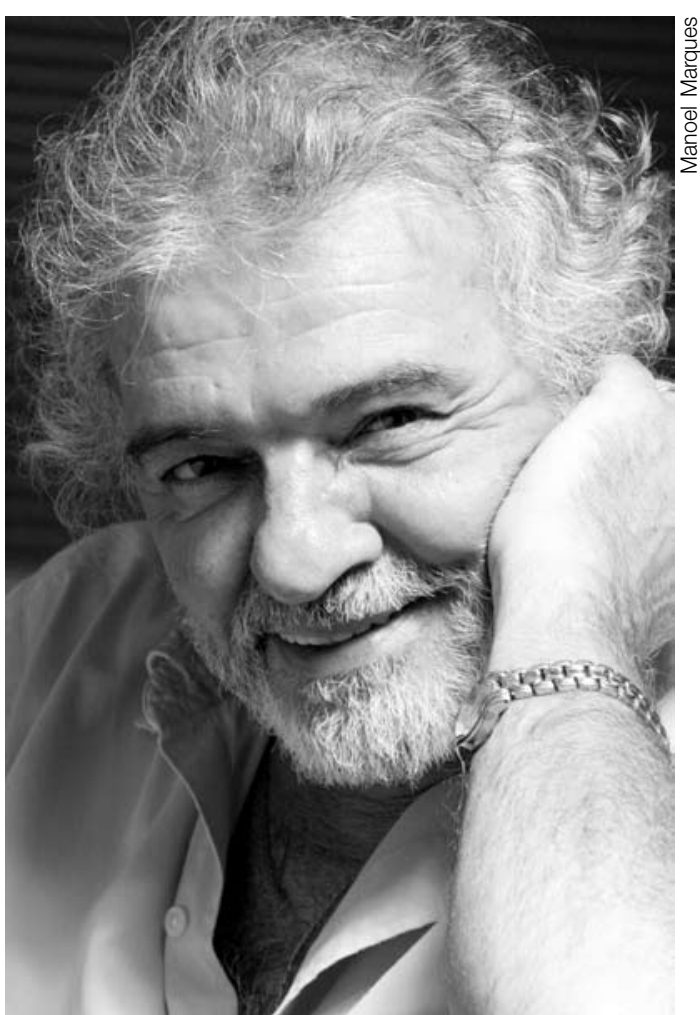

Elifas Andreato, um sobrevivente: de operário a desenhista, sempre fazendo arte com compromisso e responsabilidade social. no estêncil. Para quem não sabe o que é estêncil, é uma película onde se escreve ou se desenha, cujo suporte para impressão é o mimeógrafo. Uma coisa pré-histórica, mas em alguns lugares ainda existe. Desenhava nessa película fazendo charges, até que um dia apareceu o subgerente, que era quem mandava na fábrica. Esse homem tinha acabado de inaugurar o refeitório; ele e a assistente social, dona Gilda, uma moça gostosona, que a molecada toda cobiçava! Esse dr. Paulo queria saber quem era o desenhista... Mas ninguém sabia o que ele queria comigo, então os operários ficaram me escondendo, porque achavam que ele ia me demitir por causa das charges no jornalzinho. Passou certo tempo até que um dia um engenheiro descobriu que o homem não queria mandar o desenhista embora, mas que $o$ cara fosse ajudar a decorar o refeitório, que seria também salão de baile aos sábados à noite. Os bailes seriam promovidos pela dona Gilda, para a caixinha beneficente dos operários. Quando os operários descobriram que o chefe queria me levar para um status um pouco melhor, me entregaram. Eu era um molequinho, tinha quinze anos. Isso causou certo espanto, mas fui decorar o salão de festas. Então já comecei bem, vamos dizer assim. Comecei emprestando o meu trabalho para uma causa nobre, também em benefício próprio, é claro; era operário, mas não deixava de ser uma coisa estimulante. Nessa época, estava me alfabetizando, conseguia ler alguma coisa. Comecei a pintar com tinta de parede; não tinha o menor conhecimento de nada, mas já possuía essa vontade de mudar. Tinha um grande recalque, era muito angustiado com a minha pobreza, com as minhas dificuldades. Como filho mais velho, carregava o sonho de ajudar minha mãe. Ela era uma guerreira, cuidando dos filhos, sozinha em São Paulo, morando num cortiço, dormindo todo mundo no mesmo quarto. É espantoso como nessa idade a gente sonha... Havia um obstáculo imenso, porque além de não ter escola, mal sabia ler... o mundo aqui era muito maior, era gigantesco o mundo em São Paulo. Fiquei sonhando com isso. Na fábrica, sabia que como operário não conseguiria. Como meu pai era alcoólatra, via naqueles mecânicos o mesmo fim. Eles não tinham mais entusiasmo nenhum: trabalhavam e no fim do dia iam para o bar... era assim todos os dias. Ficava assustado. De certa maneira, sonhei fazer alguma coisa para escapar daquela 
espécie de caldeira do inferno. Precisava dar um jeito de escapar, mas com quê? Foi o desenho que me salvou! É curioso como a vida é.

Quando fui decorar o salão, também me incumbiram de selecionar as músicas que tocariam durante o almoço e de selecionar os filmes que aos sábados seriam exibidos na vila operária. Hoje, fico pensando como aquilo aconteceu; eu era uma criança! Mas entre os operários eu tinha ótima fama de ser um moleque espevitado, inquieto. Alguma coisa ali fez com que eles me delegassem essa atividade. Lembro-me de que um dos primeiro discos que comprei para tocar no refeitório foi Dois na Bossa, da Elis Regina e do Jair Rodrigues. Veja, era um salão de operários e já existia algo com qualidade diferente. Estava descobrindo o mundo, comecei a ter mais acesso a informações e a ver reconhecido meu trabalho. Não era nem um trabalho ainda, mas me ajudou a melhorar o ânimo, a elevar a auto-estima. Comecei, na fábrica, a pintar os painéis, a decorar, e fui ficando famoso. O baile dos operários tornou-se conhecido no entorno. Esse tipo de atividade cultural era muito forte na periferia; hoje, com os bailes funk acontece a mesma coisa. A população era um pouco menor, mas os hábitos e costumes permanecem os mesmos. Então fui me tornando conhecido, até que numa noite de sábado foi ao salão a Marli Medalha. Ela era crítica de arte no Diário da Noite e irmã da cantora Marília Medalha. Ela foi para lá e me descobriu como gênio, uma coisa assim. Ela viu meus quadros, pois além das pinturas decorativas, pintava uns quadros. Umas coisas terríveis. Tinham a ver com minha história, eram figuras desesperadas, crianças abandonadas, famílias desestruturadas. Felizmente não acreditei que fosse um gênio ou um menino prodígio. Mas sabia que possuía alguma coisa que não era de se jogar fora, e fui tocando. Quando fiz o cenário dos cinqüenta anos da Fiat Lux no Brasil, vieram para as comemorações uns ingleses donos da fábrica. Eles ficaram impressionados com o cenário e descobriram que eu era um menino. Como eles acharam que existisse escola de arte no Brasil, sugeriram ao gerente que me demitisse e me desse um dinheiro para eu estudar arte. Aí começou um período de sofrimento, porque saí da fábrica e o dinheiro acabou rapidinho... a família o consumiu. E fui tentar a vida como desenhista, mas o preconceito e a discriminação eram muito fortes, pois além das dificuldades que tinha com o estudo, era de uma outra classe social. Para você ver como o preconceito funciona... $\mathrm{Na}$ época talvez fosse um pouco pior do que é hoje, mas ainda é muito acentuado. Esse foi um tempo de muito sofrimento. Eu era o filho mais velho que trabalhava e de repente deixei de trabalhar para ser artista... isso seria uma tragédia para qualquer família.

A luta seguinte foi para conseguir me colocar em algum lugar e ter alguma chance como desenhista. Trabalhei em pequenos estúdios, agências, em campanhas para o varejo. Na época, não existiam os recursos que se tem hoje. Todo desenho do varejo era feito na base do desenho mesmo, clichê etc.; foi uma grande escola.

Depois de sofrer um bocado, em 1967 entrei como estagiário na Editora Abril. A Abril era uma grande empresa que estava surgindo, pagava muito bem, tinha grandes profissionais na área, especialmente jornalistas, mas também 
artistas gráficos... eram todos grandes corações, grandes almas. Dei a sorte de entrar lá por causa de um trabalho que fiz para uma pequena agência. Uma campanha destinada à Rádio Piratininga, para o programa do velho Hélio Ribeiro, radialista muito popular, que passou a dirigir a rádio Piratininga e tinha contato com essa agência. Criei para ele o slogan "espere pela boa". Como estávamos muito próximos da Editora Abril, ali perto do Teatro Municipal, chegou aos ouvidos do Atílio Basquera, diretor de arte da Abril, que havia sido um garoto o criador da tal campanha, e por isso ele me convidou. Entrei como convidado... seria diferente se eu fosse bater à porta da editora, porque era muito difícil entrar na Abril.

A partir daí começou todo o aprendizado. Fui estagiário na Claudia, convivi com Thomaz Souto Corrêa. Hoje ele é o chefão na Abril. Convivi com o Loyola, João Antônio... ali circulavam as grandes cabeças daquele momento. Fiz estágio na Claudia, depois na Quatro Rodas. Fiz a revista Manequim com a Lu Rodrigues. Ela era uma pintora maravilhosa... não sei onde anda. Ela foi uma irmã, me ensinou muita coisa. Alguns outros queriam me prejudicar. Mas a grande maioria foi muito generosa. Depois convivi com o pessoal de Realidade e comecei a perceber o contexto em que vivíamos no País. A cabeça política começou a funcionar. Já tinha certa visão por causa das condições em que vivia, da minha própria biografia, da história dos meus familiares. Mas faltava entender por que aquilo era assim. Com a convivência com eles passei a entender, tive grandes professores. Um deles ainda está comigo, o Miltainho (Mylton Severiano), nosso editor de texto no Almanaque Brasil. Outros estão por aí, como o Paulinho Patarra, que é diretor de redação; o Sérgio de Souza, que faz a Caros Amigos; o Roberto Freire, um colaborador ilustre, chefe de nossas cabeças... ele explicava melhor como funcionava essa máquina humana; é muita gente boa.

Fiz carreira muito rápido, porque tinha grande vontade de aprender e na editora passei a ter também condições materiais: prancheta, papel, tinta, revistas... Enfim, podia ficar até a hora que quisesse, desenhando e estudando. Isso foi muito bom. Mas muita gente levou um susto. Passaram a ter medo de mim, era muito ambicioso, mas não no mau sentido... tinha de aproveitar. Quando se é pobre, tem-se a impressão de que se pode perder a oportunidade que a vida lhe dá... aquela era uma chance, precisava agarrar e agarrei.

C \& E: Que importância teve na direção da sua carreira a experiência na revista Realidade? Como foi a experiência do artista, do militante no jornalismo, como isso entrou na sua história?

Elifas Andreato: Percebi que estava começando alguma coisa que não era só minha. Era um privilégio ter conseguido chegar até ali. Mas a consciência da minha própria condição e daqueles que eram parecidos comigo me dava a responsabilidade de fazer da minha atividade uma atividade solidária para que o País não continuasse tão injusto como foi comigo. Durante aquele período, com aquelas pessoas, descobri não ser capaz de ficar indiferente ao que se passava na vida dos outros brasileiros e dos seres humanos no mundo. Comecei a entender que ser humano é estar vivo dentro do planeta; portanto, qualquer 
coisa de bom ou ruim que aconteça, tem a ver com a gente. Comecei a definir que seria artista gráfico, porque não queria pintar quadro para ficar pendurado na parede de uma casa... queria me comunicar com os meus iguais.

C \& E: Você chegou a ser diretor de arte da Abril Cultural, não é?

Elifas Andreato: Quando encerrei meu ciclo de estágios, fui promovido a chefe de arte do grupo feminino na Abril Cultural. Chefiei o grupo de revistas femininas: Mãos de Ouro e uns fascículos que vendiam muito, adaptados das edições Fratelli Fabri, comprados pelo Victor Civita e adaptados aqui, por nós. Depois veio Bom Apetite, que vendia um milhão de exemplares por semana e sustentou o projeto de Veja. Era tão importante para a Editora Abril o projeto de Bom Apetite e Mãos de Ouro que a Silvana Civita, esposa do Victor Civita, foi chefiar a redação. Eu fazia aquelas revistas, mas sentia certa vergonha, porque já tinha uma consciência social, queria estar fazendo outra coisa. Achava aquele trabalho muito pequeno para um País que precisava se livrar da ditadura.

O Victor Civita me adotou, passei a ser o menino de ouro dele. Adotou mesmo! Cuidava de mim, queria saber sobre coisas como cigarros, bebidas... como um capo italiano. Victor Civita valorizava muito o lucro, a defesa do seu império, mas valoriza também o produto que ele vendia, era muito rigoroso. Aprendi o fundamental de minha profissão com ele. Eu era muito jovem e estava com aquela empáfia de me achar artista, e o sr. Victor disse-me um dia: "O mal de vocês, jornalistas, artistas, é achar que o trabalho de vocês acaba na prancheta. Não. Ele começa lá embaixo na oficina; é lá que você vai aprender como se faz uma revista”. Fui à oficina, e lá encontrei mestres italianos, gráficos, fotolitógrafos... Aprendi a fazer tudo em artes gráficas. Hoje tenho, evidentemente, dificuldades para lidar com certas tecnologias, mas naquela época fazia qualquer coisa dentro de uma empresa gráfica: fotolito, retoque, ampliação. Aprendi tudo. Esse aprendizado aumen-

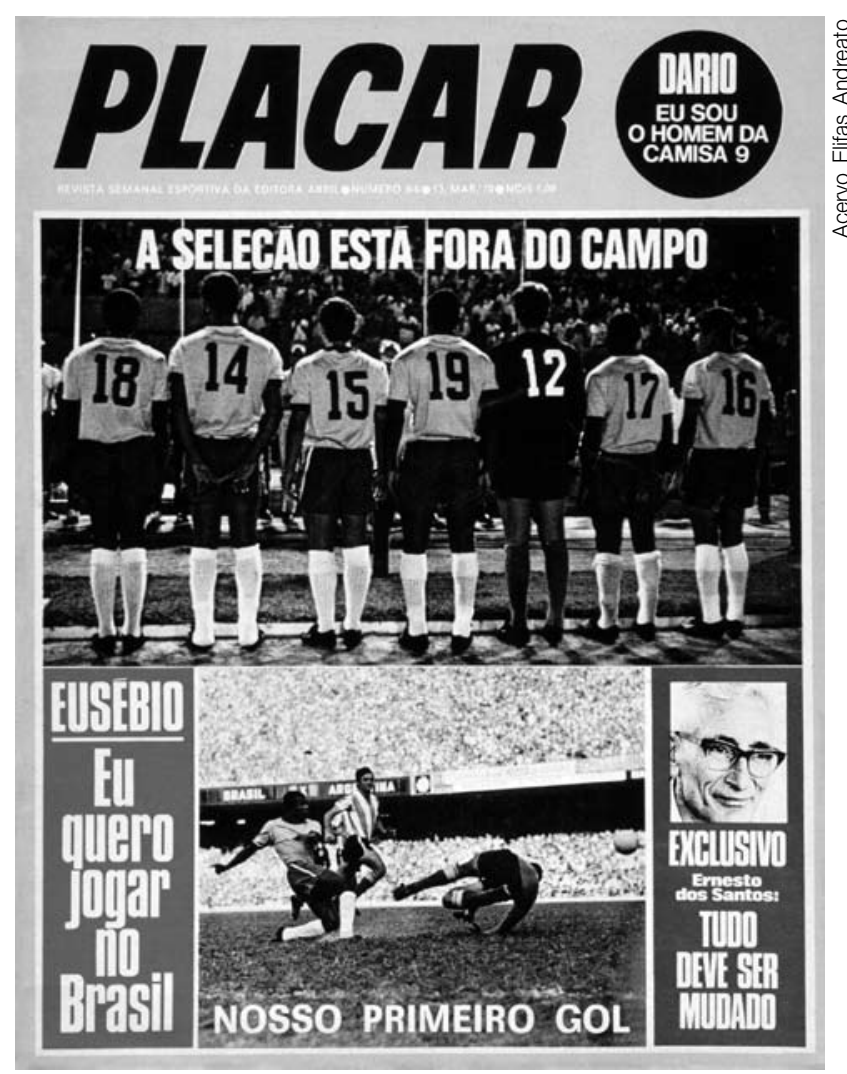

No grupo Abril, com Victor Civita, a primeira grande oportunidade, agarrada com unhas e dentes, rendeu-lhe o aprendizado fundamental da profissão e o cargo de diretor de arte. Entre outras, passou pelas revistas Claudia, Quatro Rodas, Manequim, Bom Apetite e Placar. 
tou sobremaneira meu horizonte como artista gráfico. Como desenhista sou limitado até hoje, mas aprendi a conviver com isso e a descobrir meus próprios recursos. Depois apliquei esse conhecimento na minha obra. Recursos que nenhum artista gráfico tinha na prancheta, eu já sabia onde podia encontrá-los: lá na gráfica, com a ajuda daqueles velhos amigos. Fiz minha obra toda com a ajuda daqueles trabalhadores e sou muito grato a eles; reconheço a grande contribuição que eles deram. Foi assim que comecei. Com golpes de sorte e estava no lugar certo na hora certa. No fundo disso tudo está aquela velha máxima que uso até hoje: quando se nasce pobre num país como este - acho que em qualquer lugar do mundo, mas com as diferenças tão exacerbadas como aqui —, não se pode perder nenhuma chance.

C \& E: Você acha que as empresas hoje têm espaço para jovens com histórias semelhantes à sua?

Elifas Andreato: Não. O mundo mudou muito, hoje não tem mais isso. Nós aqui, com a ajuda desse menino [Bento Andreato] e de outros, estamos tentando construir uma empresa assim. As grandes empresas, com todas as mudanças que fizeram, perderam esse perfil. Anos depois de sair da Abril, fui algumas vezes visitá-los e você não pode acreditar, aquilo virou um...

$\mathbf{C} \& \mathbf{E}:$ Você não a reconheceu mais?

Elifas Andreato: Não. Eu sou de uma fase que não existe mais. No entanto, as empresas mais sensíveis, com seus gestores de pessoas, estão buscando métodos e filosofias que contemplem o ser humano, o que eles chamam de capital humano.

C \& E: Hoje os jovens, principalmente, vêem o período da ditadura como um fato da história que se lê nos livros e poucos conhecem a importância que a imprensa alternativa, também chamada nanica, jogou na reorganização das forças democráticas. Você colaborou muito com a imprensa alternativa, não colaborou?

Elifas Andreato: Quando estava na Abril Cultural como diretor de arte, fui emprestado para fazer a revista Placar, isso mais ou menos em 1970. Juntamos a velha equipe de Realidade para fazer a Placar. Fiz o número um e voltei para a Cultural. Em seguida, entrei em um novo projeto que me lançou para fora das fronteiras da Abril; fiz os fascículos com discos sobre a História da Música Popular Brasileira. Logo depois nós fundamos, no Rio de Janeiro, o jornal Opinião, publicação alternativa contra o Regime Militar. Antes, aqui em São Paulo, tinha colaborado com o jornal EX. Enfim, participei em todas as pu-

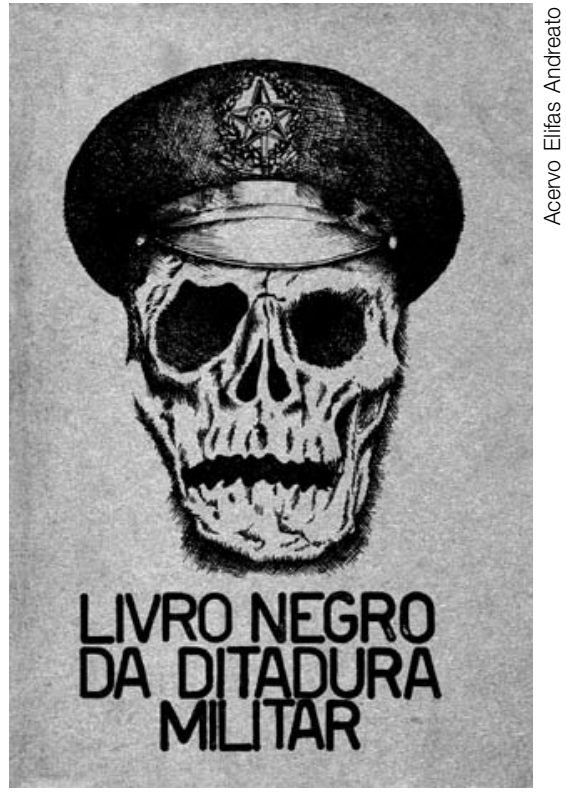

Durante a Ditadura Militar, Elifas Andreato foi um militante convicto e aguerrido que usou a arte para lutar contra o Regime. 
blicações mais alternativas e contra o Regime Militar. Por volta de 1972, fizemos aqui na Fundação Getúlio Vargas, com os centros acadêmicos de São Paulo, a contracomemoração do cinqüentenário da Semana de Arte Moderna. A partir desse momento, passei a atuar bastante... já havia realizado clandestinamente muitas colaborações, por exemplo, O Livro Negro da Ditadura Militar, o Jornal da $A P$ - Ação Popular. Os ditadores não sabiam direito como me pegar, mas quando descobriram que eu havia feito aquela capa do Livro Negro, com o quepe militar sobre um crânio, eles tentaram me pegar junto com o Azevedinho (Carlos Azevedo) e com o Raimundo Pereira. A partir daí, minha atividade ficou cada vez mais ligada aos movimentos clandestinos, realizei muita coisa. Fui assumindo a responsabilidade da consciência adquirida lá atrás na Realidade, ou seja, o meu papel de estar nas frentes de luta contra o Regime. Fundamos o jornal Opinião, no Rio de Janeiro, e aí minha vida ficou uma loucura: trabalhava na Abril de

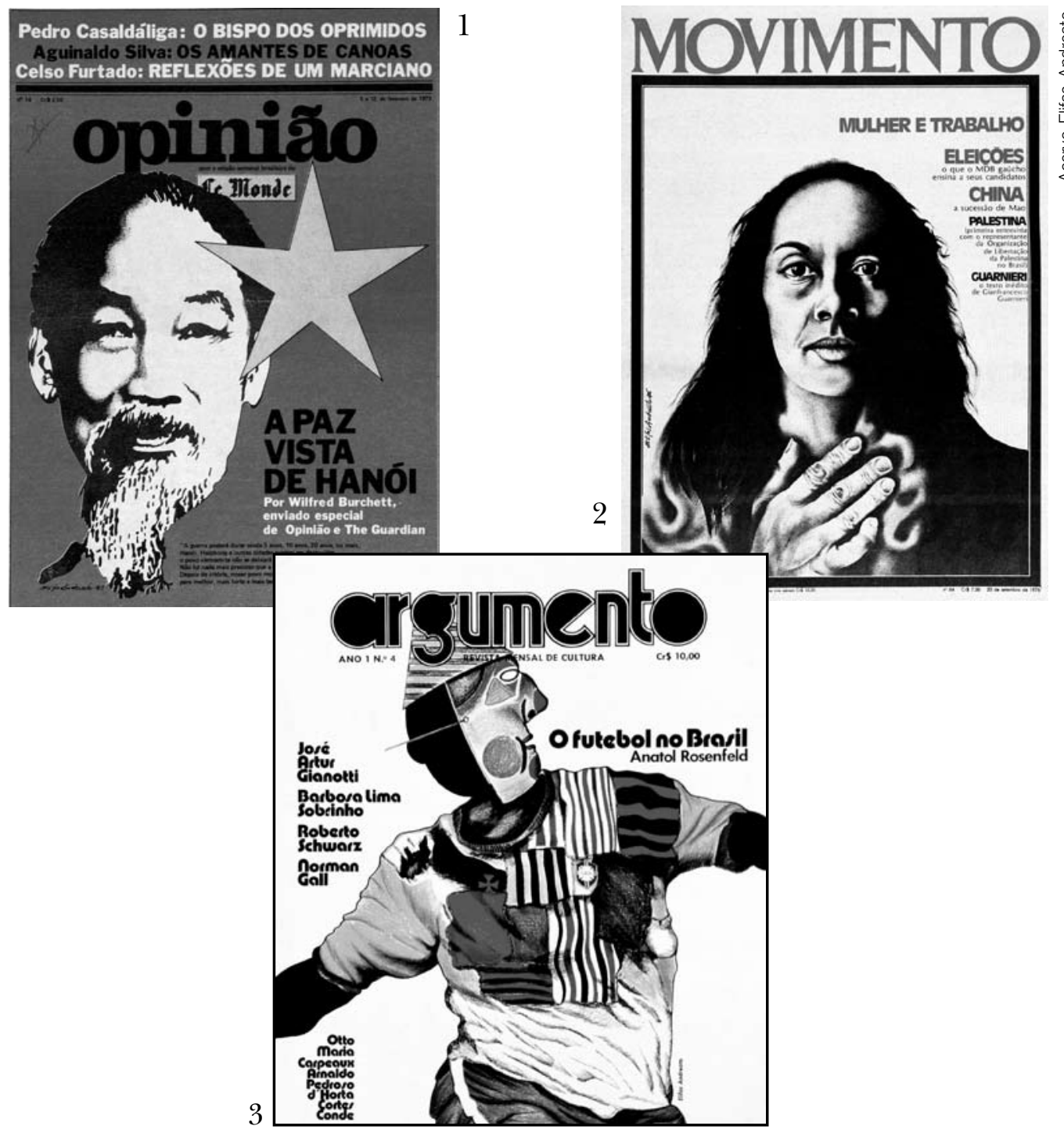

Publicações importantes dos anos 1970. 1. Jornal Opinião, publicação alternativa contra o Regime Militar 2. Jornal Movimento. 3. Argumento, a "mais bonita revista de cultura", nas palavras do prof. Antônio Cândido. 
segunda a sexta-feira; às sextas-feiras à noite ia para o Rio, trabalhava todo o fim de semana fazendo o Opinião, embaixo de censura, de pancada e tal, saía de lá domingo à noite e segunda-feira ia para a Abril direto. No mesmo período, produzi a revista Argumento com o pessoal do CEBRAP - Centro Brasileiro de Análise e Planejamento, com o Fernando Henrique, o Welfort, o professor Antônio Cândido, o Anatol Rosenfeld, enfim, criamos uma revista muito bonita. O professor Antônio Cândido disse que era a revista de cultura mais bonita que viu. Ele afirma isso no texto lindo que escreveu para o livro Impressóes ${ }^{1}$.

Voltando aos anos 1970, quando rompemos, lá no Rio, com o Fernando Gasparian, fundamos o jornal Movimento aqui em São Paulo. No Movimento, colaborava como freelance e era do Conselho Editorial. Depois de certo tempo, o Movimento também fechou. Trabalhei com o Sérgio Motta. O Sérgio fundou a Difusão para fazer teatro e para encher o saco da Ditadura. O maior exemplo disso foi com Mortos sem Sepultura, peça de Jean Paul Sartre, e também com A Morte do Caixeiro Viajante, de Arthur Miller. O cartaz de Mortos sem Sepultura, aquele do homem no pau-de-arara, foi apreendido. Nós fomos ao Teatro Maria Della Costa e a polícia estava apreendendo o material, então o Sérgio me chamou e tentei dar uma desculpa para o policial, dizer que o cartaz retratava uma situação que se passava durante a Segunda Guerra, na França, mas o policial não entrou nessa não, e me disse que o pau-de-arara era uma invenção genuinamente brasileira! Não deu para enganar.

C \& E: Você até pôs uma suástica no cartaz, mas não adiantou...

Elifas Andreato: Eles recolheram todos e, quando saíram, o Sérgio mandou imprimir mais cinco mil. Os cartões que fiz para a empresa dele, a Hidrobrasileira, eram anticartões de Natal: só miséria, pobreza... E ele dizia: "Nós temos que encher o saco dessa elite, essa elite precisa saber que o Natal no Brasil é uma miséria".

Entrei nesses movimentos todos, nessas publicações, porque passei a fazer parte de um seleto time que tinha coragem para realizar aquilo. Muita gente hoje lê a história, mas não imagina o que era de fato. Precisava ter coragem para fazer a capa do livro do Hélio Bicudo, para fazer o Capitão da Guerrilha... fiz todos eles. Nós éramos todos guerrilheiros, militantes, e toda vez que me chamaram para desenhar alguma coisa com a qual eu concordava, sempre fiz.

C \& E: Você também trabalhou como programador visual de peças de teatro, de inúmeras capas de discos, fez cenografias de shows, exposições, programas de TV. O que você mais gostou de fazer?

Elifas Andreato: Fiz muita coisa para teatro. Tenho uma coleção de cartazes de teatro que pouca gente tem. Eram todos grandes diretores, grandes autores, grandes textos. Tive o privilégio de estrear como programador visual com Caminho de Volta, de Consuelo de Castro, direção do Fernando Peixoto, com Antônio Fagundes, Otton Bastos, e cenário de Gianni Ratto. E não parei mais, porque, assim como nas capas de discos e no meu trabalho gráfico na imprensa, no cartaz para teatro consegui sempre pôr em prática as minhas 
idéias. Geralmente, desenhista é o sujeito que não estudou, uma besta ignorante, mas que tem talento para desenhar; então, o editor se acostuma a dizer para ele o que tem de desenhar. Eu havia feito um esforço danado para aprender a ler, então queria sempre ler o material para ter a minha visão, para dar o meu ponto de vista. Sempre batalhei por isso e precisei enfrentar algumas brigas para defender minhas idéias. Com essa atitude, as pessoas começaram a perceber que o cartaz de teatro não precisava ser um altar para vender o autor e o elenco, mas podia ser uma interpretação do texto, algo a mais. Essa percepção aconteceu também com ilustração para capas de livros. Fiz as capas da coleção Nosso Tempo, para a Ática. Tornei-me o ilustrador predileto dos escritores brasileiros, porque reinventei a ilustração, pois procurava traduzir visualmente o texto. A partir daí passei a ser reconhecido como uma pessoa que contribuía para aquilo que aqueles artistas queriam fazer. Muito cedo descobri que seria sempre um acessório, jamais tive a presunção de tomar o lugar do autor do livro, do disco ou da peça. Mas há muito artista

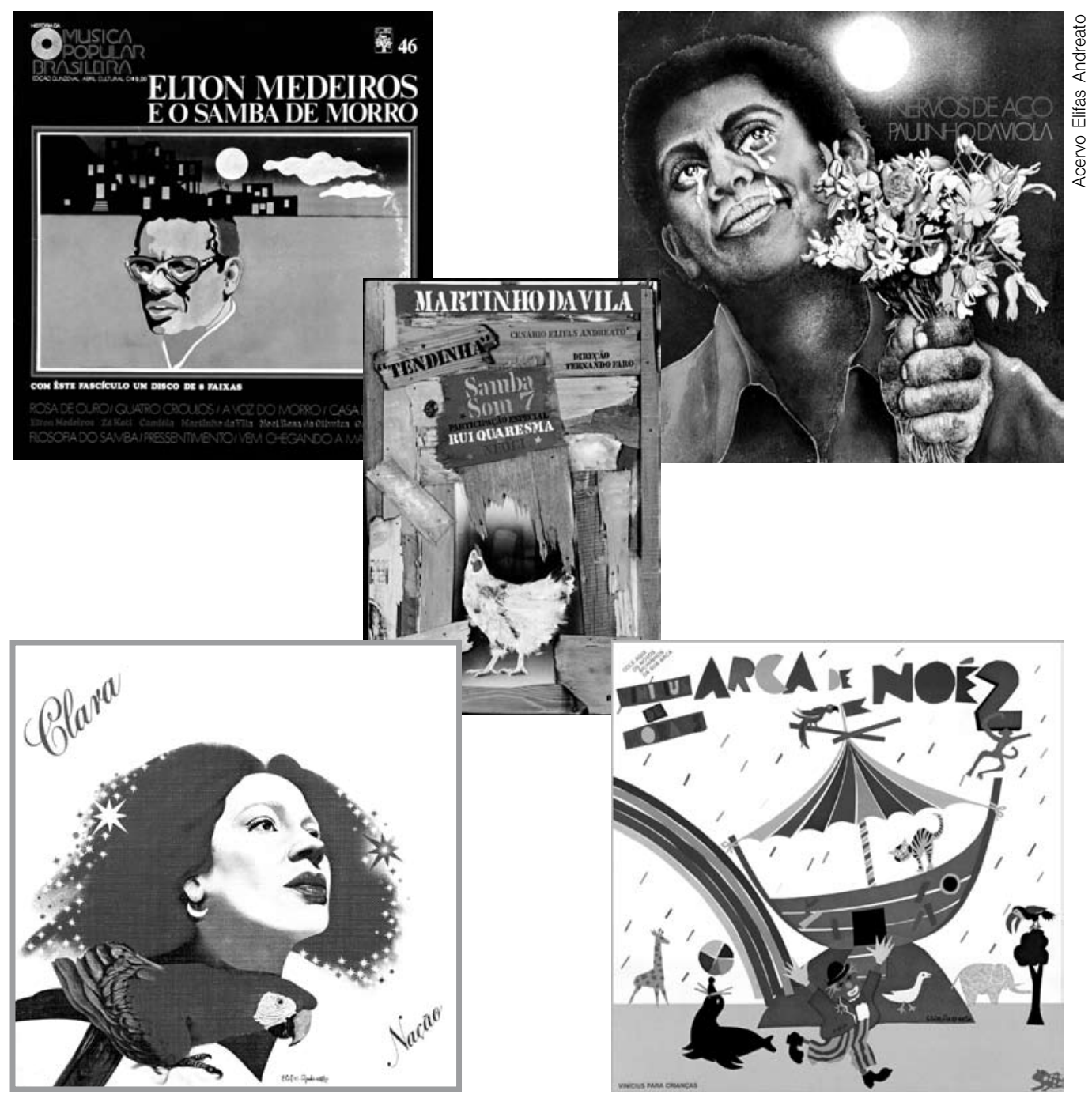

A produção de capas para discos e CDs de MPB: a cultura do Brasil sempre em primeiro lugar. 
gráfico que tenta fazer isso. Aliás, nem utilizo a palavra design, que abomino. Eu sou desenhista! Design talvez se morasse em Nova York. Eu desenho e tudo tem desenho; se você olhar a sua volta, qualquer coisa tem desenho... eles dizem que o termo design é mais amplo e desenho não é, não entendo isso! Naquele período descobri que a imagem que eu podia produzir seria essencial para convidar ou não convidar as pessoas ao acesso àquelas obras. O primeiro contato com as obras seria através do meu trabalho. Mas tinha consciência de que meu desenho não seria mais importante do que a obra que o público iria ver ou ouvir.

C \& E: Vi também que você tem brigado um pouco com o pessoal do marketing. Nem sempre as pessoas que estão à frente dessa tarefa compreendem o papel do artista gráfico na produção de uma capa de CD, de um livro, e só pensam na fórmula mais fácil para vender, não é? Elifas Andreato: Afastei-me deles, porque sou de outra época. Não sou saudosista, estou aqui com essa molecada, nessa empresa que só tem jovens; os velhinhos somos eu e o Miltainho. Todos afinados com a filosofia de trabalhar com a cultura do Brasil, sabem que esse é o caminho mais penoso, mais difícil. A minha diferença com o pessoal do marketing é que venho de um tempo em que nosso trabalho era fazer arte e o marketing vendia o que fazíamos... hoje há uma inversão. O mundo mudou, mas há regras básicas que são as mesmas, não dá para inverter. Por exemplo, o último grande artista popular para quem fiz capa de CD foi o Zeca Pagodinho. Fiz capa para ele até que voltou a vender um absurdo de discos. Nesse momento, todo mundo sabia como tinha de ser a capa. Então desisti, não fiz. Queriam me dizer como seria a capa. Assim não precisam de mim. O marketing acha que tem de ter imagem, porque o Zeca é sexy, as mulheres gostam, é símbolo sexual. Bom, se o Zeca Pagodinho é um símbolo sexual, eu estou fora do mundo, pode tratar disso com quem você quiser, porque não entendo mais nada. Aconteceu que o marketing virou o que sabe tudo, não tem espaço para nós. E de certa forma esse negócio vem funcionando, tanto que nós, digo as pessoas de minha geração, por exemplo, um

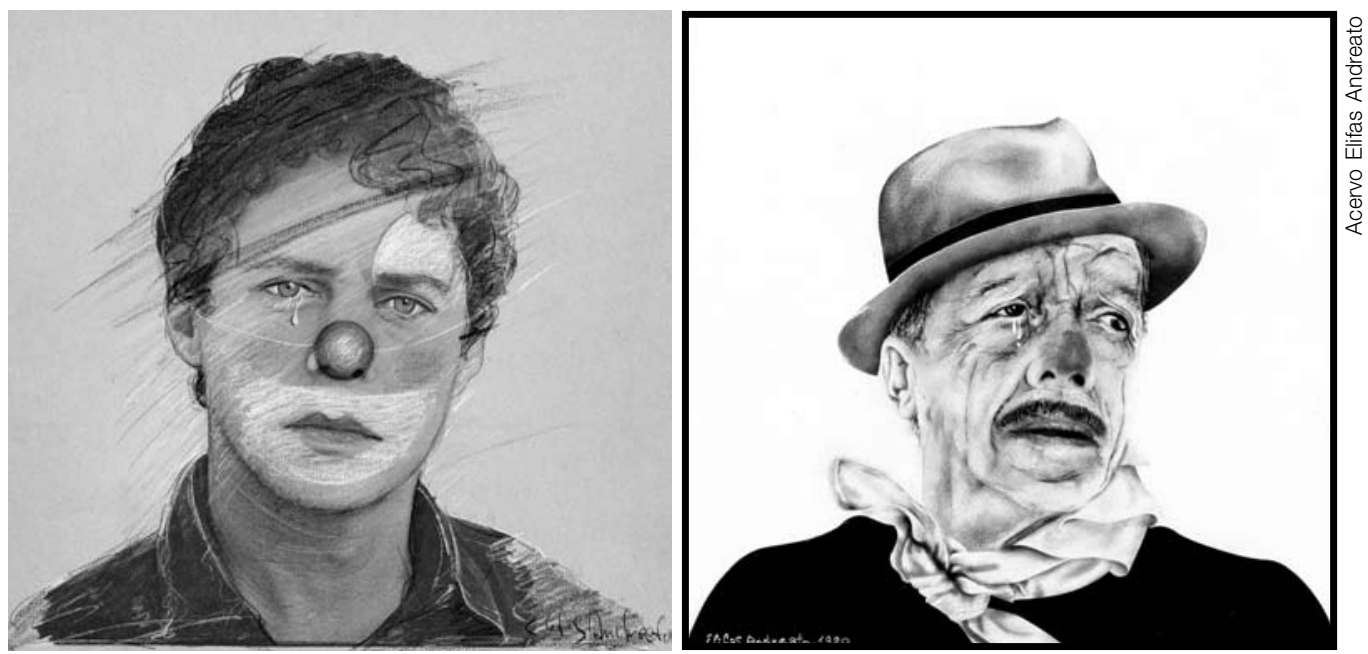

Chico Buarque e Adoniran Barbosa: expressões marcadas, fortes, com opinião, características da arte de Elifas Andreato. 
gênio da raça como é o Chico Buarque está descontente; o Paulinho da Viola também. Os marqueteiros dizem que ninguém quer ouvi-los, ninguém quer comprá-los, ninguém quer saber daquele tipo de trabalho. Fazem isso porque sabem que não dá para chegar no Chico e dizer como é que ele tem de fazer o disco dele. Então eles também não vendem o Chico.

C \& E: Você acha que esses profissionais dos meios de comunicação, profissionais do mercado, especificamente esses voltados para a indústria cultural, têm feito com que a população emburreça?

Elifas: Têm. Eles fazem um esforço diário. Li recentemente e recomendo para todo mundo o livro Como eu me tornei um estúpidoz; é um livro francês. O Chico disse uma frase outro dia que é verdade, desconfio até que tenha lido esse livro. Ele disse recentemente que o mundo está medíocre - não é bem essa a expressão -, e ele tem medo de ficar assim. Na verdade, é um esforço diário para que isso aconteça. O nivelamento foi descendo, descendo, e hoje é aquela história... Exemplo atualíssimo é o da minissérie $J K^{3}$ (da Globo) e a estréia de Big Brother. A minissérie $J K$ estreou com $46 \%$ de audiência e a Globo tratou rapidinho de colocar o Big Brother antes e jogou a minissérie à meia-noite... a audiência caiu para $17 \%$ e o Big Brother ficou com $50 \%$ ! Esse é o projeto. O projeto de emburrecimento... a mídia brasileira funciona assim.

C \& E: Não é um paradoxo: no mundo com tanta tecnologia e acesso à informação, $e$ essa informação não serve para o conhecimento?

Elifas Andreato: Depende a quem serve o conhecimento. Nós temos uma elite que insiste que o conhecimento deve ser prioridade dela, a massa tem de continuar ignorante. Por que será que uma série que começa tão bem como $J K$ é torpedeada de uma maneira absurda por um Big Brother? Primeiro, porque o interesse do brasileiro médio é pelo Big Brother. A audiência de $46 \%$ para $J K$ seria bacana se o programa tivesse continuado no mesmo horário. Não teria concorrência: sai da novela, vai para a minissérie. A Maria Adelaide está chateada, porque prejudicaram um trabalho muito bem-sucedido e, do ponto de vista histórico e cultural, seria importante para o público conhecer o País daquela época, qual a importância, os erros, os acertos, enfim. Ela é uma pessoa responsável! E, no entanto, é muito mais importante para a inteligência brasileira, para a mídia brasileira, para os marqueteiros do Brasil, o Big Brother.

C \& E: Vende...

Elifas: Vende e a ele se atrelam produtos, e aquilo vira uma maluquice. Aí é que está a mediocridade, porque aquilo é quase doença.

C \& E: Para mim é patológico.

Elifas Andreato: Agora, vivemos neste mundo! Fazemos entrevistas mensais com grandes brasileiros, e sempre chegamos à mesma conclusão óbvia: ou educamos esse povo ou nós vamos ficar correndo em círculos, atrás do rabo, nessa mediocridade.
2. PAGER, Martin. Como me tornei um estúpido. Rio de Janeiro: Rocco, 2005. 160 p.

3. De Maria Adelaide Amaral. Direção de Dennis Carvalho. Jan./mar. 2006. 
C \& E: Arrisco pensar que não basta a educação formal, escolar, curricular. Pois nesse caso são os formados, os educados que estão deseducando os outros.

Elifas Andreato: Concordo com você. É um investimento pra valer. Formar para a cidadania!

C \& E: Você tem uma agência de comunicação. Não tem?

Elifas Andreato: É, ela pode ser classificada dessa forma. Chama-se Andreato, Comunicação e Cultura ${ }^{4}$.

\section{C \& E: Você tem feito que tipo de trabalho?}

Elifas Andreato: Nós editamos o Almanaque Brasil e fazemos muitas outras coisas. $\mathrm{Na}$ verdade, todo nosso trabalho está voltado para a cultura brasileira. Defini um estilo, uma preocupação e um foco, e a empresa está cuidando disso. Hoje nós estamos trabalhando em várias frentes. Fazemos projetos especiais para empresas. Estamos trabalhando em dois grandes projetos para a TAM: um livro com o centenário do vôo do Santos Dumont para a celebração dos trinta anos da TAM, e outro, que é o álbum de família, um trabalho sobre a história da empresa contada pelos funcionários. Também fiz uma grande exposição, no final do ano passado, no Palácio do Planalto, com a Declaração dos Direitos da Criança. Trata-se de um concurso que o MEC realiza a partir de frases enviadas de todos os Estados. Criei vinte e seis esculturas bem bonitas, tendo como tema os Direitos da Criança. Este ano estou fazendo uma outra exposição com valores humanos. Estou trabalhando nessa área. Estamos fazendo também alguns DVDs e projetos grandes, estamos trabalhando com o grupo Positivo, que é um grupo de ensino no Paraná. Vamos organizar uma série de projetos para eles, todos ligados à educação. Também trabalhamos ligados a eles em um projeto mais pessoal: vou editar meus livros infantis. Estou elaborando um novo disco infantil com o Toquinho, Na casa do tempo. Vai sair um disco, também infantil, com o Tom Zé... fiz as letras e o Tom Zé musicou; chama-se Sem você não há. Tenho um projeto grande de livros para crianças, pois sempre estive muito próximo desse trabalho e agora, já envelhecendo, acho que trabalhar com criança é sempre uma possibilidade de renovação, de renascimento. Estou pondo para fora os velhos projetos. Fizemos muita coisa bacana em 2005 e estamos começando a planejar e já apavorados com a quantidade de coisas que temos para realizar em 2006. É um trabalho bastante diversificado, que tem em comum o foco na cultura brasileira. Temos com a Nestlé vários projetos: além do Ponto Cívico, participamos do projeto Nutri e ainda, do projeto Viaje Nestlé pela Literatura, que fazemos todo ano. Enfim, o perfil é esse.

C \& E: E com relação às artes gráficas? Você disse logo no início que o mundo mudou e uma coisa que mudou muito foi a realidade da produção gráfica. Ou seja, aqueles senhores que lhe ensinaram, lá na gráfica da Abril, todo o processo de produção, não existem mais. Como é para você a relação com as novas tecnologias? Sua arte se viabiliza por esse novo caminho?

Elifas Andreato: As ferramentas são magníficas. Temos a facilidade, a sorte de ter vivido todo o processo e chegado a esse estágio maravilhoso. Aqui expe- 
rimentamos tal tecnologia diariamente. Para uma pessoa como eu, que viveu a pré-história do linotipo e hoje se senta ao lado de um garoto que trabalha no photoshop ${ }^{5}$, restaurando imagens, é maravilhoso. Em qualquer outro tempo, mesmo há dez anos, esse material seria perdido... hoje temos o orgulho de estar certos de mantermos aqui o maior acervo de música popular brasileira restaurado, em função dos projetos que fizemos sobre a história do samba, da MPB. Vivo encantado com essa tecnologia, porque nada mais é impossível, qualquer documento pode ser salvo... para o artista gráfico é o paraíso. Um dia desses achei no meu álbum de coisas guardadas um cartão que o Paulinho da Viola me deu, todo amassado. Peguei aquilo com uma satisfação, porque em outro tempo estaria perdido; hoje eu digo: "no photoshop restaura". Não é maravilhoso? Martinho da Vila um dia me deu uma foto, a única que tinha do pai, uma foto $3 \times 4$ de um documento. O Martinho me pediu: "Ô compadre, será que a gente consegue melhorar essa foto?”. Disse a ele que faria um retrato bem grande e bacana, e fiz. Nossas exposições, no Projeto Memória, por exemplo, com esse sistema que a gente usa de restauração, paginação, é uma coisa ótima. Fiz a exposição JK no Congresso Nacional a partir da leitura da autobiografia de Juscelino; restaurei tudo. Convivo muito bem com a tecnologia, mas fiz a seguinte opção: trabalho na prancheta e sei que aquilo ali é uma ferramenta. Não posso entender que a máquina vá me substituir. Essa é a confusão que os meninos fazem, pensam que o programa resolve tudo. Não resolve tudo. A máquina é uma ferramenta, como uma aquarela, um pincel, enfim. Sei que é uma ferramenta eficiente, mas é só uma ferramenta... não dá para achar que a ferramenta resolve o problema.

C \& E: $O$ que você acha importante para a formação desses jovens que optam por ser desenhistas, seguir a carreira e produzir na área das artes gráficas?

Elifas Andreato: $\mathrm{O}$ fundamental para qualquer profissional é se formar primeiro como ser humano. O jovem precisa ter a dimensão da condição humana e da sua insignificância. Precisa estudar, ter uma formação ampla, uma base cultural forte. A primeira coisa que recomendo é estudar e estar antenado com as coisas que estão acontecendo nas áreas culturais: exposições, museus, eventos, tudo isso faz parte do nosso universo. É importante para a formação de qualquer pessoa que lide com comunicação. O domínio do equipamento é a coisa mais simples. O estudo de línguas é importante, fundamental. Para o aproveitamento dos recursos de informação que temos na atualidade, é essencial ter um sistema de filtro eficiente, ser crítico, senão a gente se perde. Eu mesmo estou ficando angustiado, porque tenho muita coisa para fazer e não dá tempo. Preciso ler muito para escrever meus livrinhos. Não dá para sair escrevendo... Então, voltando à sua pergunta, a formação humanista é o mais importante. O resto, eles nasceram com as máquinas, aprendem em três, quatro dias; fazem o diabo com essas máquinas.

C \& E: Você continua a colaborar com os movimentos sociais?

Elifas Andreato: Menos do que eu gostaria, mas tenho colaborado.
5. Software para processamento e edição de imagens da Adobe Systems Incorporated. Disponível em: <http://pt.wikipedia. org/wiki/Adobe_Photo shop>. Acesso em: 11 mar. 2006. [N.E.] 
C \& E: Onde andam os movimentos sociais?

Elifas Andreato: O movimento social hoje de peso é o Movimento dos Sem-Terra; fora disso, você vai ter ONGs... Quando me pedem as coisas, eu faço. Toda vez que encontro o Stédile (João Pedro Stédile, uma das lideranças nacionais do MST - Movimento dos Sem-Terra), ele me pede coisas impossíveis; antes éramos mais humildes. Hoje, ele chega pra mim e pede 50 mil Almanaques! Então, há coisas que ficam difíceis. O Betinho, por exemplo, era uma pessoa que mobilizava, mas, como dizia um amigo, com senso de noção, ele pedia o possível. Atendo a muitos desses movimentos, mas dentro das nossas possibilidades. Fizemos, por exemplo, uma exposição e um musical dedicados ao Carlos Marighella, para a Clara Charf, com o Vladimir Sachetta. Fazemos muito isso.

C \& E: Parece-me que os movimentos populares estão com dificuldade para se organizar. Qualquer um funda uma ONG, faz um projeto e manda para o governo e o movimento popular mesmo não tem recursos.

Elifas Andreato: A opção que fizemos, considero-a necessária para o nosso momento. Estamos ligados a empresas que realizam esse tipo de projeto social e que nos remuneram mal, mas de qualquer maneira é uma forma de estarmos colaborando e, ao mesmo tempo, mantermos uma estrutura que ainda é muito dependente de receita. Fui aprendendo com o tempo que deixei de ser sozinho; hoje tenho alguns meninos com uma carreira pela frente, começando a vida, e acho que ser responsável, nesse caso, é viabilizar esse futuro. A minha prioridade hoje é viabilizar a empresa, ter a possibilidade de estar ligado a trabalhos sociais e, ao mesmo tempo, viabilizar um futuro... Quando se tem tal clareza de objetivos, sem culpa, seguro de que está fazendo uma coisa correta, é mais fácil superar as dificuldades que aparecem no dia-a-dia. Isso aqui foi uma conquista, não minha, mas do grupo. Resolvemos criar uma pequena empresa para funcionar bem, pagar as pessoas, os credores e que possa também

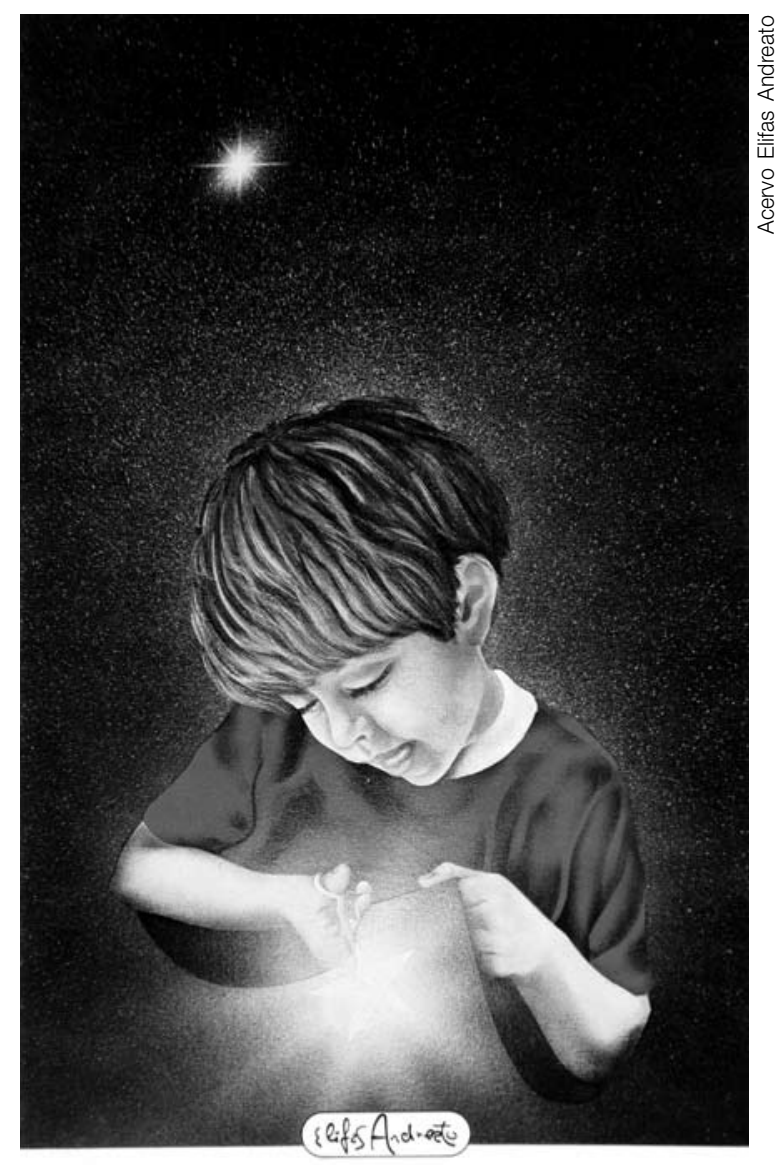

Viabilizando um futuro melhor. A Andreato Comunicação e Cultura tem a missão de construir idéias, conceitos, produtos e serviços que valorizem a gente, a arte e a cultura brasileira, contribuindo para o auto-conhecimento e desenvolvimento dos brasileiros e do Brasil. 
estar associada a outros projetos sociais. Não dá para fazer isso sem estar bem... Como ajudar os outros se você está esfarrapado? Não dá.

C \& E: E quando você vai fazer uma exposição dos seus trabalhos?

Elifas Andreato: Este ano completo 60 anos. Há um grupo trabalhando para uma exposição e para um livro novo. Vamos aguardar.

Resumo: O entrevistado deste número é o artista gráfico Elifas Andreato, com quem Roseli Fígaro dialoga, resgatando a trajetória de seus passos iniciais de jovem operário desenhista, sua evolução artística e orientação política, até o reconhecimento e consagração de sua arte e talento. Muitos não conhecem o artista, que optou pelas artes gráficas para não deleitar apenas as paredes das belas casas e dos museus. Começou com as pinturas do salão de festas na fábrica, migrou e expandiu-se para as capas de revistas, para as charges nos jornais alternativos, para os cartazes das peças de teatro, para as capas de discos e depois CDs da MPB, para os cenários no teatro, na televisão, para as ilustrações em livros, para as músicas e os livros infantis, tudo feito com opinião. Faz arte com respeito à vida, à liberdade e com compromisso coletivo. A camaradagem está estampada nas figuras que contam histórias, há mais de quarenta anos pintadas em cores firmes.

Palavras-chave: Elifas Andreato, artes gráficas, teatro, televisão, imprensa alternativa.
Abstract: In this issue, the interviewed person is the graphic artist Elifas Andreato, with whom Roseli Fígaro dialogs, recovering the trajectory of his first steps of young worker designer, his artistic evolution and political orientation until the recognition and sanction of his art and talent. Many people do not know the artist that chose graphic arts to go beyond the walls of beautiful houses and museums. He began with paintings in the party room of the factory, migrated and expanded to magazine covers, cartoons in alternative newspapers, posters of theater plays, Brazilian Popular Music albums covers, scenery in theater and television, book illustrations, music and children books, all of them marked by his opinion. He makes art respecting life, freedom and collective commitment. The comradeship is stamped in the figures that tell the stories and more than 40 years painted with strong colors.

Keywords: Elifas Andreato, graphic arts, theater, television, alternative press 